\title{
OVERCONFIDENCE AND EFFECT ON FIRM FINANCIAL DECISIONS IN THE CONTEXT OF BEHAVIORAL CORPORATE FINANCE
}

\author{
Bilgehan Tekin \\ Faculty of Economics and Administrative Sciences \\ University of Cankiri Karatekin, Republic of Turkey
}

\begin{abstract}
In this study it is examined the effect of managerial overconfidence on financial decisions. The financial decisions that into account in this research are consist of capital structure, investment and dividend payment. Survey method was used for data collection purpose. The survey contains questions that measure overconfidence and to obtain information about financial decisions and about the participants. The study covers 255 companies operating in Istanbul. Parametric and nonparametric hypothesis tests were performed to analyze the data. As a result of the study, found that the managers had a high degree of overconfidence bias and this bias had a certain level of influence on the financial decisions.
\end{abstract}

Keywords: Behavioral Finance, Behavioral Corporate Finance, Overconfidence, Financial Decisions.

\section{INTRODUCTION}

As Hackbarth (2008) indicates the actors who are involved in the system and act in financial markets are generally assumed as rational and have homogeneous expectations in traditional economics and finance theories. Traditional assumption accepts that the company managers take the decisions concerning their companies as rationally as seen in investors. Goldfarb et al., (2012) emphasis that this understanding was adopted in the course of empirical and theoretical studies in the field of economics. Traditional finance

models based on rational behavior and decision paradigm generally assume that managers aim to maximize the present value of their current and future earnings, solve a dynamic optimization problem, or play a Nash Equilibrium. However, some of the researches show that these and similar traditional assumptions are frequently violated (Goldfarb et al., 2012). Numerous studies in the field of 


\section{ELK ASIA PACIFIC JOURNAL OF FINANCE AND RISK MANAGEMENT}

ISSN 2349-2325 (Online); DOI: 10.16962/EAPJFRM/issn. 2349-2325/2015; Volume 9 Issue 4 (2018)

experimental psychology have shown that people often behave far away from traditional economic paradigms and that they may be overly optimistic about future events or overconfidence in their ability and knowledge (Hackbarth, 2008).

As Chow et al. (2011) indicates, with the increasing number of academic studies, it is seen that individuals do not act as rational as traditional economics suggest. Simon (1955), who raises bounded rationality, criticizes the rational economic paradigm with the following words: "The classical theory of omniscient rationality is strikingly simple and beautiful. Moreover, it allows us to predict (correctly or not) human behavior without stirring out of our armchairs to observe what such behavior is like. All the predictive power comes from characterizing the shape of the environment in which the behavior takes place. The environment, combined with the assumptions of perfect rationality, fully determines the behavior. Behavioral theories of rational choice theories of bounded rationality-do not have this kind of simplicity. But, by way of compensation, their assumptions about human capabilities are far weaker than those of the classical theory. Thus, they make modest and realistic demands on the knowledge and computational abilities of the human agents, but they also fail to predict that those agents will equate costs and returns at the margin".

A behavioral corporate finance approach has emerged with a view to examining the effects of the teachings and findings of behavioral finance on the decisions taken in companies and especially on managers' decisions. The common result of researchers who work in this field such as Heaton (2002), Malmendier \& Tate (2005a, 2005b), Fairchild (2009) is that managers are not fully rational decision makers. When the financial decisionmaking processes in companies are examined by taking into consideration the behavioral finance area, it is seen that these decisions have been taken according to Simon' s (1957) "bounded rationality" rather than full rationality. The reasons for irrational decisions are psychological factors such as emotion, intuition, judgment and bias. Busenitz and Barley (1997) stated that behavioral biases include the following three elements;

(1) Decision making methods used by individuals to assist decision-making processes,

(2) Cognitive mechanisms and

(3) Personal opinions. 


\section{ELK ASIA PACIFIC JOURNAL OF FINANCE AND RISK MANAGEMENT}

ISSN 2349-2325 (Online); DOI: 10.16962/EAPJFRM/issn. 2349-2325/2015; Volume 9 Issue 4 (2018)

The success of the companies in the strong competitive environment that exists between the companies operating today depends on the decisions of the managers and the degree of hit these decisions. One of the main duties of the managers and the company owners is to be able to guide the financial decisions that will ensure the value of the firms, the welfare of the stakeholders and the growth. Even though these managers are well educated, experienced and expert in decision making, they act mostly under the influence of their human nature and cognitive, behavioral characteristics and biases.

In this study, the effect of overconfidence, which is one of behavioral biases and frequently study in behavioral finance literature, on the financial decisions taken in small and medium-sized enterprises is examined. The study also includes the literature, analysis and conclusions parts of the study titled "Impact of Behavioral Biases on Financial Decisions of Firms" that was previously published as a $\mathrm{PhD}$ thesis by Tekin (2015).

\section{LITERATURE REVIEW}

Overconfidence can be expressed in different ways except "bias". Overconfidence is expressed as "tendency" in some researches such as Yates, Lee \& Shinotsuka (1996), Grinblatt \& Keloharju (2009); as "miscalibration" in Skala (2008), Michailova \& Schmidt (2016); as "heuristic" in Simon \& Houghton (1999), Zahra, Yavuz \& Ucbasaran (2006) and as "illusion" in Fromlet (2001), Bhandari \& Deaves (2006). Even though there are differences in expressions, the common results of the studies conducted in the context of overconfidence are the following; overconfidence individuals are exaggerating both their predictive abilities and the reliability of their information.

The overconfidence was first discussed in 'Case-Study Judgments in Overconfidence' conducted by Oskamp (1965). Oskamp (1965) investigated whether psychologists' confidence in their decisions about their patients is realistic or not and indicated that the level of accuracy of people' decisions are not significantly correlated with the increase in the level of confidence of people. The level of accuracy of the decisions made by the individuals increased not with respect to the degree of trust, but increase with the confidence of them. This is attributed to the overconfidence of clinical psychologists in their decision making. 


\section{ELK ASIA PACIFIC JOURNAL OF FINANCE AND RISK MANAGEMENT}

ISSN 2349-2325 (Online); DOI: 10.16962/EAPJFRM/issn. 2349-2325/2015; Volume 9 Issue 4 (2018)

In psychology literature, overconfidence refers to the unrealistic confidence of individuals about their abilities and knowledge (Odean, 1998). Overconfidence is the tendency of people to exaggerate their abilities, confidence in their knowledge, expectations of success, positive outcomes of events. It occurs as a result of people not knowing the limits of their knowledge.

Overconfidence bias arises from the fact that decision-makers are overly optimistic in the initial evaluation stages. This makes it difficult for individuals to include additional information that they later acquired, because their overconfidence does not allow it (Fischhoff, Slovic \& Lichtenstein, 1977; Alpert \& Raiffa 1982).

The first example of research on the impact of overconfidence on the corporate decision-making process of companies is based on the study of Roll (1986) (Hribar \& Yang, 2016). Roll (1986) focused on merger and acquisition decisions in companies. In this study, Roll proposed the hypothesis of "Hubris Hypothesis" and observed that the firm executives overpaid the takeover decisions. Roll has explained the reasons for not giving up of managers' excessive bids in the tenders in spite of the fact that they will not make a real return in acquisitions. Roll put forward the Hubris Hypothesis as the cause of this situation.

Baker \& Wurgler (2013) divided the finance literature as rational manager and investor behaviors and less rational manager and investor behavior. They call the effect of manager behavior as 'managerial biases (tendencies)'. The most important bias in managerial biases is overconfidence. Overconfidence is an important psychological factor that continues to be the subject of many international studies in the area of behavioral corporate finance.

Glaser \& Weber (2007) argue that the number of studies examining the impact of overconfidence bias on financial decisions is not sufficient. They also state that overconfidence models are a summary of the results of multiple psychological studies.

Contrary to traditional financial assumptions, the assumption that the actors in the financial system and financial markets do not act fully rationally is accepted widely day by day. Palomino \& Sadrieh (2011) state that these studies mostly focus on overconfidence behavioral bias. 


\section{ELK ASIA PACIFIC JOURNAL OF FINANCE AND RISK MANAGEMENT}

ISSN 2349-2325 (Online); DOI: 10.16962/EAPJFRM/issn. 2349-2325/2015; Volume 9 Issue 4 (2018)

It is stated that there is a relationship between financial alternative preferences of firm managers and their level of overconfidence. In some of these studies, it is stated that managerial overconfidence cause more external debt (Shefrin, 1999; Hackbarth, 2008; Fairchild, 2009) and in some other studies indicate that overconfident managers prefer to use more firm profit (Malmendier et al., 2011). At the same time, it is argued that the overconfident company managers prefer short-term debt (Landier \& Thesmar, 2009) because of the fact that their expected return of their investment projects are overestimate and they don't consider enough their probability of loss. Based on these studies, one of the hypotheses to be tested within the scope of the study was formed as follows;

H1: The alternatives used in financing the activities differ according to the level of overconfidence.

In the literature, it is also suggested that the value of the cash flow expected by the overconfident company managers from their investments will be higher than the actual cash flows (Malmendier \& Tate, 2008; Hirshleifer et al., 2012). On the other hand, it is stated that the overconfidence bias may cause investment projects that are likely to be damaged but to be perceived as profitable investments (Malmendier \& Tate, 2004; Gervais et al., 2003; Kim, Zhang \& Wang, 2016; Iyer, Sankaran \& Nejadmalayeri, 2017). The second and third hypotheses to be tested in this context are as follows:

H2: The difference between the return that the business managers expect to obtain from their investments and the yield they actually obtain differs according to their level of overconfidence.

H3: There is a relationship between the frequency of loss of investment projects that managers perceive as profitable investments and their level of overconfidence.

The studies that examined the impact of overconfidence on dividend distribution decisions suggest that dividend payments are low in the firms that managed by overconfident managers (Cordeiro, 2009; Deshmukh et al., 2013). According to the results of some other studies if the expected cash flows from the investments are high, high levels of dividend are paid in companies that managed by overconfident managers (Ben-David et al., 2007; Wu and Liu, 2011; Deshmukh et al., 2013). Based on these studies, the fourth and fifth hypotheses are formed as follows: 


\section{ELK ASIA PACIFIC JOURNAL OF FINANCE AND RISK MANAGEMENT}

ISSN 2349-2325 (Online); DOI: 10.16962/EAPJFRM/issn. 2349-2325/2015; Volume 9 Issue 4 (2018)

H4: The dividend distribution rate differs according to managers overconfidence level.

H5: There is a relationship between overconfident managers' expected rate of return and dividend distribution rate.

\section{METHOD}

\section{MEASUREMET METHODS}

Different measurement methods and scales can be used in situations and studies that require measurement of overconfidence bias, depending on the research interests of the researchers, the subject they research and the structure of the sample. In addition, numerous studies on overconfidence indicate that this bias can never be directly observed (Glaser and Weber, 2007). Barber and Odean (2001), for example, have taken the gender as a measure of overconfidence based on the findings of previous studies in psychology. There are no traditional methods of measuring overconfidence of participants in economic and financial research. Therefore, methods used to measure overconfidence vary from study to study. For example, Glaser and Weber (2007) directly measured the overconfidence of a group of individual investors with the psychological survey they prepared online.
Researchers such as Malmendier and Tate (2005, 2008), Humphery-Jenner, Lisic, Nanda and Silveri (2016) made a measurement based on the option transactions of managers.

In this study, confidence interval survey and calibration score (CALSCO) will be used to measure overconfidence, which has been used in previous studies (Lichtenstein, Fischhoff \& Phillips, 1982; Alpert \& Raiffa, 1982; Russo \& Schoemaker, 1992; Klayman, Soll, Gonzales-Vallejo \& Barlas, 1999; Johnson \& Allwood, 2003; Biais, Hilton, Mazurier \& Pouget, 2005; Parker \& Fischoff, 2005; Keh et al., 2002; Michailova, 2010) and has been given more reliable results (Klayman et al., 1999) than other methods.

The overconfidence measure consists of 10 questions and the correct answer to the respondents' responses to these 10 questions will be calculated according to the number of coverage (Appendix 1). In literature searching step of the study it is observed that the confidence intervals and the number of errors that using for calculation of CALSKO are taken into account in different ways. Number of error was taken as $20 \%$ by Klauss (2006) and $10 \%$ by Russo and Shoemaker (1992). In this study this ratio was determined as $30 \%$ 


\section{ELK ASIA PACIFIC JOURNAL OF FINANCE AND RISK MANAGEMENT}

ISSN 2349-2325 (Online); DOI: 10.16962/EAPJFRM/issn. 2349-2325/2015; Volume 9 Issue 4 (2018)

by considering the difficulty levels of the questions. Studies that had been made in the international field and mentioned in the literature section have been taken into consideration while determining this ratio. The confidence interval in the account of CALSCO is determined as $70 \%$ considering the difficulty of the questions. CALSCO was calculated by the following formula (Klauss, 2006; Glaser \& Weber, 2007);

\section{Calibration $=1-\frac{10-\text { number of error }}{7}$}

Well-calibrated participant will make at most 3 errors so CALSCO will be 0 or negative values and this participant will be a "rational participant". In this study, if the participant's response to all questions that does not include the correct answer, the participant will exhibit "strong overconfidence" (In this case calibration score will be "1"). Conversely, if all the answers cover the correct answer, this participant will be characterized as "rational, underconfidence or low overconfidence" (Russo \& Schoemaker, 1992; Simon, Houghton \& Aquino, 2000; Fitzzsimmos \& Douglas, 2005; Klauss,
2006). In this case calibration score will be approximately “- 0,43 ”.

Keasey \& Watson (1989) stated that overconfidence would increase with the difficulty level of the questions and called this case as difficult-easy effect or task complexity. The difficulty is measured by the percentage of correct answers (Gigerenzer, Hoffrage \& Kleinbölting, 1991).

\section{DATA COLLECTION AND ANALYSIS METHOD}

A structured questionnaire was applied in the data collection method of the study. The questionnaire consists of 4 main parts. These are questions about the participants, firms, financial decisions and overconfidence. The questionnaire was applied by face to face interview with 255 firms which are registered to Istanbul Chamber of Commerce and Industry Chamber. According to TUIK business records approximately 846,507 enterprises are active in Istanbul (TUIK, 2014). The number of companies operating in Istanbul with limited liability and joint stock companies is around 15.781 (14.810 Limited and 971 companies) according to 2009 data (TUIK, 2012). According to the sample size table in the $95 \%$ confidence interval, it is sufficient to have a sample 
size of 375 in the case where the main mass is 15.781 (Yazıcıŏglu \& Erdoğan, 2004). On the other hand, it was desired to reach a majority representing all SMEs in Istanbul, but it was not possible to reach this number due to reasons such as time and cost constraints and not being filled in by the respondent. In total, approximately 420 companies were contacted and 262 of them completed the questionnaire and 255 of them were found to be suitable for analysis. The survey was conducted between 01 August 2015 and 31 October 2015.

Parametrical (one sample $t$ test, independent groups $t$ test, one-way analysis of variance, correlation analysis) and non-parametric (Kruskal Wallis, Mann Whitney U) hypothesis tests were used for the analysis. The normal distribution, which is a prerequisite for applying parametric analysis methods, was evaluated from descriptive statistics by considering skewness (or curvature) and kurtosis values. These values are within the range of +1.5 to -1.5 or between +2.0 and -2.0 are considered sufficient for normality (Tabachnick \& Fidell, 2013; George \& Mallery, 2010).

The results were evaluated at a level of $p$ $<0.05$ and the mean values were considered to be acceptable. In addition, frequency analysis and descriptive statistics were used for the creation of hypotheses and interpretation of results.

\section{FINDINGS}

As a result of the questionnaire application, information about the participants are shown in (Ref Table 1).

Accordingly, it is seen that the persons responsible for the financial decisions in the companies covered by the sample are primarily the company owner, then the company manager, third the financial manager and finally the accounting manager. At this point, the owners of the company are also the managers (owner manager). The issue that is particularly emphasized in the survey is whether the participant has an impact on the financial decisions taken in the firms. This situation was reported to the participant orally during the questionnaire application and it was taken into consideration. On the other hand, it is known that the accounting managers working in the firms can be held responsible for taking the basic financial decisions within the scope of the transfer of authority. In summary, this study was discussed with the authorized and responsible people about the financial decisions taken in the companies. 


\section{ELK ASIA PACIFIC JOURNAL OF FINANCE AND RISK MANAGEMENT}

ISSN 2349-2325 (Online); DOI: 10.16962/EAPJFRM/issn. 2349-2325/2015; Volume 9 Issue 4 (2018)

The majority of the firms in the study are companies that have been in operation for 16 years or more. $67.5 \%$ of the companies are limited liability companies and $32.5 \%$ are joint stock companies. Care was taken that the sample of the study consisted of companies dominated by institutional and organizational culture.

Another question is to determine whether the company is a family company or not. In table we see that $51.8 \%$ of the companies are family companies. The majority of the firms (78.8\%) were independent companies which are not part of a company group. The total number of employees in the companies is between 10 and 49 with $76.5 \%$. Hence, more small scale firms have been the subject of this study. Manufacturing industry (food, forest products and furniture, textiles, other manufacturing) with a maximum of $37.6 \%$ and the firms operating in the wholesale and retail trade sector with a rate of $23.9 \%$ constituted the sample of this study. The gender of the participants was generally male $(71.4 \%)$ and $61.6 \%$ of the participants were married. The ages of the participants were mostly between the ages of $26-35(40.8 \%)$. Note that although the firm age is generally 16 years and above, the participants are mostly in the younger age group. This situation can be interpreted as an indicator of the fact that there are more youth in the management level. When the educational status of the participants is examined, it is seen that the majority of them (42.4\%) are undergraduate. When we look at the positions in the enterprise, it is seen that the participants who are the most senior managers are the subjects of the study. The work experience of the company managers of the companies is mostly (45.5\%) between 1-5 years.

\section{HYPOTHESIS TESTING}

Overconfidence levels of the managers of the company were measured by a overconfidence scale of 10 questions. Accordingly, the correct answer to the responses of the participants in the interval is the percentage of coverage as shown in (Ref Figure 1) below.

As shown in Figure 1, the answers show a normal distribution. The accuracy rate of answers is $28 \%$. This means that approximately 3 of the participants' answers to 10 questions cover the correct answer. The low percentage of correct answers indicates a high level of overconfidence. Because in normal circumstances and with a rational approach, if the questions are difficult for 
the participants, the participant is expected to keep the range of questions wide at the rate of difficulty of the questions, so that the answer can include the correct answer. When the numbers written in the bar graphs are examined, it is seen that the correct answer percentage of 134 of 255 participants is in the range of $15 \%$ to $35 \%$. The other participants were almost equally distributed around these percentages.

As mentioned in the part of measuring overconfidence level of the study, the participant with CALSCO " 0 " is defined as a rational participant. Accordingly, this value will be taken into account when testing the following hypothesis. The hypothesis that the company managers have in order to test their self-confidence prejudice is as follows:

$H_{0}$ : Company managers are not overconfident (they are fully rational).

\section{$H_{1}$ : Company managers are overconfident}

(they are not fully rational).

In order to test this hypothesis, a single sample t-test was performed. The results of the test are described below.

As seen in (Ref Table 2), the $p$ value is less than 0.05 and the difference between the two means is 0,6858 . There was a significant difference between the expected value 0 and the average CALSCO 0,6858. In this case, the hypothesis $\mathrm{H}_{0}$ is rejected and it is concluded that the participants are overconfident individuals. As a result of this analysis, it has been concluded that the managers of the company are overconfident.

While this result is reached, the graph in Figure 2 is taken into consideration. As can be seen from the graph, the average of the overconfidence of 255 firms is approximately 0.69 . The standard deviation is 0.183 and the distribution of overconfidence levels is normal. The numbers falling in the middle of the bars indicate the number of participants in the overconfidence interval. The line connecting the peaks of the bars is the interpolation line. (Ref Figure - 2)

While calculating the overconfidence average, the following steps were followed; firstly, the data collected by the confidence interval survey were analyzed and it was calculated how many of the 10 questions (corrected 1, wrongs 0) were answered by the respondents. As shown in the table below, the average correct response rate was approximately $28 \%$. The median value is $30 \%$ and the most common value is $30 \%$. The low rate of correct response to the questions is an 


\section{ELK ASIA PACIFIC JOURNAL OF FINANCE AND RISK MANAGEMENT}

ISSN 2349-2325 (Online); DOI: 10.16962/EAPJFRM/issn. 2349-2325/2015; Volume 9 Issue 4 (2018)

indication of the high degree of difficulty of the questions for the participants. (Ref Table - 3)

In the next step of the study CALSCO was calculated. According to the financing source used in financing the activities, the results of Kruskal Wallis one-way variance analysis are shown in (Ref Table 4).

As a result of the Kruskal Wallis, it was observed that the alternatives used as the source of financing did not differ according to overconfidence level $(0,886>$ $0.05)$. This is clearly seen when looking at the average sequence values. The financing alternative decisions used in the financing of activities were not changed according to the CALSCO scores $(0,177>.05)$. This is also observed in the average sequence values (Ref Table 5).

Similarly, there is no statistically significant difference between the financing alternatives according to the CALSCO scores $(0,509>0.05)$. Again, it is seen that the average sequence values are close to each other (Ref Table 6).

According to these results, the alternatives used by the company managers to finance their activities do not change according to their level of confidence. On the other hand, in the emergence of this result, it is effective that the sample structure and research methods used in the study are different from other studies in the literature. Therefore, this situation should not be overlooked in evaluations. However, it is clear from the frequency table that overconfidence participants prefer to use their undistributed dividends in the financing of their activities, they prefer to borrow from their partners secondly and they prefer the short-term debt as a third preference over long-term borrowing. It is important to take into consideration the impact of firms' wishes to minimize the cost of capital and the problems they face in reaching financing sources in the formation of this ranking.

In order to test the second hypothesis of the study, the answers given to the questions in Table 8 and the CALSCO were examined. (Ref Table 7) presents descriptive statistics and frequency distributions of the answers given to the questions. Accordingly, the average return expected from the investments made by the overconfidence participants in their activities is 3.69 and the actual return from the investments is $2.47^{1}$.

\footnotetext{
${ }^{1}$ These means were calculated according to the coding that made during data analysis. These encodings are included in parenthesis in Table 8.
} 
In (Ref Table 8), it is observed that most of the participants get $10 \%$ and below (91) of the yield, while the return they expect to achieve is highest in the range of $21 \%$ $30 \%(55)$.

As a result, the overconfident participants expect a higher rate of return than their investment. One-way variance analysis was performed in order to test whether the participants differed according to their level of overconfidence.

In order to test this hypothesis, the difference between the expected return and the yield obtained for each participant was calculated and the DIFFERENCE variable was obtained. Then, the relationship between DIFFER and CALSCO was analyzed by one way variance analysis. According to the Table 10, the difference between the expected and realized rates of return does not change according to the level of overconfidence (sig. 0.584>0.05). Note that these results are obtained according to overconfidence levels. However, the participants were shown to be overconfidence individuals with the results of the One Sample $t$ test. Therefore, when the tables with frequencies and means are given (Table 7, 8 and 9), it is seen that the expected rate of return is higher than the rate of return and supports the findings in the literature. (Ref Table 10)

This situation can also be observed in the correlation analysis (Ref Table 11). The following table shows the correlation analysis between CALSCO and two variables.

Accordingly, a negative-weak relationship between CALSCO and the rate of return is mentioned. Thus, as the literature suggests, the higher the overconfidence level cause the lower the rate of return from investments. The findings obtained from the analyzes show that the overconfident participants' expected return rate more than realized return rate. However, the higher of the overconfidence rating cause the lower rate of return at a weak form.

In order to test the third hypothesis of the study, the frequency of losses from the investments that the participants perceived as profitable investments were measured. The answers to the question are as shown in the (Ref Table 12) below. The answers given to this question, which is normally measured with 5-point Likert-type scale, were grouped into 3 groups to combine cells with very low number of observations. Accordingly, the majority of the participants stated that they rarely suffer from investment projects that they 
perceive as a profitable investment (73.7\%).

Kruskal Wallis test was used to determine whether this situation has a relationship with the level of overconfidence bias. According to the analysis, frequency of losses from projects perceived as a profitable investment is independent from overconfidence (significance $0,446>0,05$ ). On the other hand, the number of participants indicating that they are faced with such investments is very high when the frequency table (Table 12) is taken into consideration. This, in part, supports the finding that the above-mentioned overconfidence decision makers have misrepresented these projects by making inaccurate valuations in the process of valuation of investment projects. (Ref Table - 13)

The dividend payment rates of the firms have been determined in order to examine the relationship between dividend dividend payment rates and overconfidence. According to (Ref Table 14), it is observed that the dividend ratios are concentrated between $1 \%$ and $20 \%$.

H4 hypothesis was then tested. (Ref Table 15) shows the results of one-way variance analysis related to $\mathrm{H} 4$ hypothesis. $\mathrm{H} 4$ hypothesis was accepted because the significance was $0.038<0.05$. Therefore, it is concluded that the rate of dividend payment differs according to the level of overconfidence.

Scheffe test results were examined in order to determine which groups are related to this difference. According to the Scheffe test results, there is a significant difference between low overconfidence group and high overconfidence groups in terms of dividend payment rates (significance 0.046 $<0.05)$. (Ref Table - 16)

As shown in (Ref Table 17), the average dividend payment of participants with low overconfidence is 3.19 , while the average of high-overconfidence participants is 2.51. Accordingly, the rate of dividend paid by the participants in the low overconfidence group was higher than the other groups and $\mathrm{H} 4$ hypothesis was confirmed.

In order to test the H5 hypothesis, firstly the data set was edited. While doing this, participants with high confidence level were determined and their responses to expected return and dividend distribution rates were analyzed. The Table 18 shows overconfidence levels. According to this, the number of participants with high level of confidence is 86. (Ref Table - 18) 


\section{ELK ASIA PACIFIC JOURNAL OF FINANCE AND RISK MANAGEMENT}

ISSN 2349-2325 (Online); DOI: 10.16962/EAPJFRM/issn. 2349-2325/2015; Volume 9 Issue 4 (2018)

Whether there is a relationship between the responses of 86 people with high overconfidence to the questions has been tested by correlation analysis. According to the results, there was a relationship between two variables because the significance was less than 0,036 significance level. The force of the relationship is low and positive (Pearson's correlation coefficient is 0.227 ). According to these results, if the level of expected cash flows or expected return rates is high, the rate of dividend payment is also high. This is due to the belief that overconfidence behavioral bias leads to the company managers to exaggerate the success and return rates they expect from their investments and that their dividend ability level will be high in the future and that they will not experience liquidity problems. (Ref Table - 19)

\section{CONCLUSION AND DISCUSSION}

Traditional finance theory suggests that the decisions such as capital structure, investment and dividend distribution aim to maximize dividends of shareholders with a normative perspective. When the studies are examined in related literature, it is seen that the majority of them are based on this assumption. However, it is noteworthy that efforts to develop behavioral finance and behavioral corporate finance disciplines have increased in recent years against the traditional rational finance paradigm.

Researchers such as Statman (1999) and Thaler (1999) state that scientists interested in financial models need to make the best and most accurate assumptions about behavior in all existing models, rather than developing a number of submodels with empirically observed behaviors.

Contrary to traditional finance, the fact that information and financial decision processes of individuals are influenced by the factors of cognitive and emotional bias is increasingly accepted. One of these biases is overconfidence. In the literature, this bias which is considered in terms of investor behaviors has been examined in the context of the decisions taken in companies in this study.

Overconfidence is defined as a factor that causes individuals to exaggerate their chances of success in any business because of their belief that the best decision in relation to a decision situation will be given by them that they have superior abilities and that events take place in their control. 


\section{ELK ASIA PACIFIC JOURNAL OF FINANCE AND RISK MANAGEMENT}

ISSN 2349-2325 (Online); DOI: 10.16962/EAPJFRM/issn. 2349-2325/2015; Volume 9 Issue 4 (2018)

In this study, the effects of financial decisions on firms and the behavioral biases of managers in decision makers of firms have been tried to be put forward. The main financial decision situations faced by the firms in the period of their activities were determined as capital structure, investment and dividend decisions. The results of analyzes are summarized as follows; (1) the managers of the firms examined within the scope of the study exhibit high level of overconfidence. (2) While there is no statistically significant relationship between the overconfidence level and capital structure decisions, the overconfidence bias may lead to short-term debt being preferred over long-term debt. (3) The expected return on the investments made by the company manager who are overconfident is higher than the actual return. However, as the overconfidence level increases, the return on investments is decreasing. The low level of overconfidence of the company manager and /or owners has been revealed by misrepresenting their investment projects. (4) The rate of dividend share paid by the company managers, which have higher overconfidence have been paid lower dividend than the others. The dividend distribution rate decreases as the level of overconfidence increases. If the expected rate of return from current investments is high for a manager then the dividend share rates also being high.

According to the results of the study, there is a certain relationship between behavioral biases and financial decisions parallel to the literature. In firms, decision-makers should provide a more effective and consistent decision-making process by taking into account the findings of traditional corporate finance, as well as the impact of behavioral and psychological factors on decision-making processes.

\section{REFERENCES}

Alpert, M., \& Raiffa, H. (1982), A Progress Report on the Training of Probability Assessors. In Judgment under Uncertainty: Heuristics and Biases, edited by Daniel Kahneman, Paul Slovic, and Amos Tversky. Cambridge: Cambridge Univ. Press.

Baker, M. \& Wurgler, J. (2013). Do Strict Capital Requirements Raise the Cost of Capital? Banking Regulation and the Low Risk Anomaly (No. w19018). National Bureau of Economic Research. https://www.stern.nyu.edu/sites/default/file 


\section{ELK ASIA PACIFIC JOURNAL OF FINANCE AND RISK MANAGEMENT}

ISSN 2349-2325 (Online); DOI: 10.16962/EAPJFRM/issn. 2349-2325/2015; Volume 9 Issue 4 (2018)

s/assets/documents/con_044678.pdf

Accessed on: 09/07/2015

Ben-David, I., Graham, J. R. \& Harvey, C. R. (2007). Managerial overconfidence and corporate policies (No. w13711). National Bureau of Economic Research.

Bhandari, G. \& Deaves, R. (2006). The demographics of overconfidence. The Journal of Behavioral Finance, 7(1), 5-11.

Biais, B., Hilton, D., Mazurier, K. \& Pouget, S. (2005). Judgemental overconfidence, self-monitoring, and trading performance in an experimental financial market. The Review of economic studies, 72(2), 287-312.

Busenitz, L. W. \& Barney, J. B. (1997). Differents between entrepreneurs and managers in large organizations: Biases and heuristics in strategic decision-making. Journal of business venturing, 12(1), 9-30.

Chow, E. H., Lin, H. M., Lin, Y. M., \& Weng, Y. C. (2011). The performance of overconfident fund managers. Emerging Markets Finance and Trade, 47(2), 21-30.

Cordeiro, L., (2009) Managerial Overconfidence and Dividend Policy, Available at SSRN:http://ssrn.com/abstract=1343805or http://dx.doi.org/10.2139/ssrn.1343805

Accessed on: 08/11/2014

Deshmukh, S., Goel, A. M. \& Howe, K. M. (2013). CEO overconfidence and dividend policy. Journal of Financial Intermediation, 22(3), 440-463.

Fairchild, R. (2009). Managerial overconfidence, moral hazard problems, and excessive life cycle debt sensitivity. Investment Management and Financial Innovations, 6(3).

Fischhoff, B., Slovic, P. \& Lichtenstein, S. (1977). Knowing with certainty: The appropriateness of extreme confidence. Journal of Experimental Psychology: Human perception and performance, 3(4), 552.

Fromlet, H. (2001). Behavioral FinanceTheory and Practical Application. Business Economics, 36(3), 63-63.

George, D. \& Mallery, M. (2010). SPSS for Windows Step by Step: A Simple Guide and Reference, 17.0 update (10a ed.) Boston: Pearson.

Gervais, S., Heaton, J. B. \& Odean, T. (2003). Overconfidence, Investment Policy, and Executive Stock Options. https://pdfs.semanticscholar.org/79ba/4e87 
49693e0d078b503751984a4dd4737006.pd

f, Accessed on: 08/09/2015

Gigerenzer, G., Hoffrage, U. \& Kleinbölting, H. (1991). Probabilistic mental models: a Brunswikian theory of confidence. Psychological review, 98(4), 506.

Glaser, M. \& Weber, M. (2007). Overconfidence and trading volume. The Geneva Risk and Insurance Review, 32(1), 1-36.

Goldfarb, A., Ho, T. H., Amaldoss, W., Brown, A. L., Chen, Y., Cui, T. H., ... \& Xiao, M. (2012). Behavioral models of managerial decision-making. Marketing Letters, 23(2), 405-421.

Grinblatt, M. \& Keloharju, M. (2009). Sensation seeking, overconfidence, and trading activity. The Journal of Finance, 64(2), 549-578.

Hackbarth, D. (2008). Managerial traits and capital structure decisions. Journal of Financial and Quantitative Analysis, 43(04), 843-881.

Heaton, J. B. (2002). Managerial optimism and corporate finance. Financial management, 31(2), 33-45.

Hirshleifer, D., Low, A. \& Teoh, S. H. (2012). Are overconfident CEOs better innovators? The Journal of Finance, 67(4), 1457-1498.

Hribar, P. \& Yang, H. (2016). CEO overconfidence and management forecasting. Contemporary Accounting Research, 33(1), 204-227.

Humphery-Jenner, M., Lisic, L. L., Nanda, V., \& Silveri, S. D. (2016). Executive overconfidence and compensation structure. Journal of Financial Economics, 119(3), 533-558.

Iyer, S. R., Sankaran, H., \& Nejadmalayeri, A. (2017). CEO overconfidence and agency cost of debt: An empirical analysis of CEO turnover events. The North American Journal of Economics and Finance, 42, 300-313.

Kim, J. B., Wang, Z., \& Zhang, L. (2016).

CEO overconfidence and stock price crash risk. Contemporary Accounting Research, 33(4), 1720-1749.

Klauss, P., C., (2006), Capital Investment Decisions with Managerial Overconfidence and Regret Aversion, $\mathrm{PhD}$ Thesis, University of Bath School of Management, England.

Klayman, J., Soll, J., Gonzalez - Vallejo, C. \& Barlas, S. (1999). Overconfidence: It depends on how, what, and whom you ask. 


\section{ELK ASIA PACIFIC JOURNAL OF FINANCE AND RISK MANAGEMENT}

ISSN 2349-2325 (Online); DOI: 10.16962/EAPJFRM/issn. 2349-2325/2015; Volume 9 Issue 4 (2018)

Organizational Behavior and Human

Decision Processes, 79, 216 - 247.

Landier, A. \& Thesmar, D. (2009).

Financial contracting with optimistic entrepreneurs. Review of financial studies, 22(1), 117-150.

Lichtenstein, S., Fischhoff, B., \& Phillips, L. D. (1977). Calibration of probabilities: The state of the art. In Decision making and change in human affairs (pp. 275-324). Springer, Dordrecht.

Lichtenstein, S., Fischhoff, B. \& Phillips, L. D. (1982). Calibration of Probabilities: The State of the Art to 1980, in Judgment Under Uncertainty: Heuristics and Biases 306, 321-22 (D. Kahneman, P. Slovic \& A. Tversky eds. 1982).

Malmendier, U. \& Tate, G. (2005a). CEO overconfidence and corporate investment. The journal of finance, 60(6), 2661-2700.

Malmendier, U. \& Tate, G. (2005b). Does overconfidence affect corporate investment? CEO overconfidence measures revisited. European Financial Management, 11(5), 649-659.

Malmendier, U. \& Tate, G. (2008). Who makes acquisitions? CEO overconfidence and the market's reaction. Journal of financial Economics, 89(1), 20-43.
Malmendier, U., Tate, G. \& Yan, J. (2011). Overconfidence and early-life experiences: the effect of managerial traits on corporate financial policies. The Journal of finance, 66(5), 1687-1733.

Michailova, J. \& Schmidt, U. (2016). Overconfidence and bubbles in experimental asset markets. Journal of Behavioral Finance, 17(3), 280-292.

Michailova, J. (2010). Overconfidence and bubbles in experimental asset markets. https://mpra.ub.uni-

muenchen.de/30579/1/MPRA_paper_3057

9.pdf, Accessed on:10/08/2013

Odean, T., 1998. Volume, volatility, price and dividend when all traders are above average. J. Finance, (53), 1887-1934.

Oliver, B. R. (2005) The Impact of Management Confidence on Capital Structure. Available at SSRN: http://ssrn.com/abstract=791924 or http://dx.doi.org/10.2139/ssrn.791924 , Accessed on:10/05/2015

Oskamp, S. (1965). Overconfidence in case-study judgments. Journal of consulting psychology, 29(3), 261.

Palomino, F. \& Sadrieh, A. (2011). Overconfidence and delegated portfolio 


\section{ELK ASIA PACIFIC JOURNAL OF FINANCE AND RISK MANAGEMENT}

ISSN 2349-2325 (Online); DOI: 10.16962/EAPJFRM/issn. 2349-2325/2015; Volume 9 Issue 4 (2018)

management. Journal of Financial Intermediation, 20(2), 159-177.

Parker, A. M. \& Fischhoff, B. (2005). Decision-making competence: External validation through an individual differences approach. Journal of Behavioral Decision Making, 18(1), 1-27.

Russo, J. E. \& Schoemaker, P. J. (1992). Managing overconfidence. Sloan Management Review, 33(2), 7-17.

Simon, H. A. (1955). A behavioral model of rational choice. The quarterly journal of economics, 69(1), 99-118.

Simon, M. \& Houghton, S. M. (1999). The effects of cognitive heuristics on strategic action: overcoming the risk hurdle to first move. New England Journal of Entrepreneurship, 2(1), 35.

Simon, M., Houghton, S. M. \& Aquino, K. (2000). Cognitive biases, risk perception, and venture formation: How individuals decide to start companies. Journal of business venturing, 15(2), 113-134.

Skała, D. (2008). Overconfidence in Psychology and Finance-an Interdisciplinary Literature Review. Bank $i$ Kredyt, (4), 33-50.
Statman, M. (1999). Behaviorial finance: Past battles and future engagements. Financial Analysts Journal, 55(6), 18-27.

Tabachnick, B.G, Fidell L.S. (2013), Using Multivariate Statistics (sixth ed.) Pearson, Boston.

Tekin, B. (2015), The Impact of Behavioral Biases on Firms' Financial Decisions (Firmalarm Finansal Kararlarl Üzerinde Davranışsal Önyarglların Etkisi), PhD Thesis (Doktora Tezi), Sakarya University Institute of Social Sciences, Sakarya, Turkey.

Thaler, R. H. (1999). Mental accounting matters. Journal of Behavioral decision making, 12(3), 183-206.

TUIK (2014), http://www.tuik.gov.tr/PreHaberBultenleri. do?id=18521, Accessed on:10/03/2015

TÜiK, (2012), http://www.tuik.gov.tr/PreHaberBultenleri. do?id=13146, Accessed on:10/03/2015 Yates, J. F., Lee, J. W., \& Shinotsuka, H. (1996). Beliefs about overconfidence, including its cross-national variation. Organizational Behavior and Human Decision Processes, 65(2), 138-147. 


\section{ELK ASIA PACIFIC JOURNAL OF FINANCE AND RISK MANAGEMENT}

ISSN 2349-2325 (Online); DOI: 10.16962/EAPJFRM/issn. 2349-2325/2015; Volume 9 Issue 4 (2018)

Yazıcioğlu, Y. \& Erdoğan, S. (2004). Spss

Uygulamalı Bilimsel Araştırma

Yöntemleri. Ankara: Detay Yayıncılık.

Zahra, S. A., Yavuz, R. I. \& Ucbasaran, D. (2006). How much do you trust me? The dark side of relational trust in new business creation in established companies. Entrepreneurship theory and practice, 30(4), 541-559.

\section{Appendix 1. Overconfidence Scale}

\begin{tabular}{|c|c|c|}
\hline & \multicolumn{2}{|c|}{$\begin{array}{l}70 \% \text { confidence } \\
\text { intervals }\end{array}$} \\
\hline & $\begin{array}{l}\text { Maximu } \\
\mathrm{m}\end{array}$ & $\begin{array}{l}\text { Minimu } \\
\mathrm{m}\end{array}$ \\
\hline What is the number of tourists visiting Turkey in $2014 ?$ & & \\
\hline What is the per capita income in Turkey in 2014 ? & & \\
\hline $\begin{array}{l}\text { How many passengers did Istanbul Atatürk Airport serve in average } \\
\text { in } 2014 \text { ? }\end{array}$ & & \\
\hline What is the number of vehicles per 1000 people in Turkey in 2014 ? & & \\
\hline What is the unemployment rate in Turkey in 2014 ? & & \\
\hline What is the total number of companies established in Turkey in $2014 ?$ & & \\
\hline $\begin{array}{l}\text { What is the number of patents registered by the Patent Institute of } \\
\text { Turkey in Turkey in 2014? }\end{array}$ & & \\
\hline $\begin{array}{l}\text { What is the total number of people working in research and } \\
\text { development activities of the company in Turkey in } 2014 \text { ? }\end{array}$ & & \\
\hline What is the total number of female managers in Turkey in $2014 ?$ & & \\
\hline $\begin{array}{l}\text { What is the number of German-based firms in the world's top } 500 \\
\text { firms list published by Fortune Business Magazine in 2014? }\end{array}$ & & \\
\hline
\end{tabular}

\section{LIST OF TABLES: -}

Table 1: Frequency Table

Person that Responsible for

Financial Decisions 
ISSN 2349-2325 (Online); DOI: 10.16962/EAPJFRM/issn. 2349-2325/2015; Volume 9 Issue 4 (2018)

\begin{tabular}{|c|c|c|}
\hline Accounting Manager & 18 & 7,1 \\
\hline Finance Manager & 59 & 23,1 \\
\hline Business owner & 91 & 35,7 \\
\hline Business Manager & 87 & 34,1 \\
\hline Total & 255 & 100,0 \\
\hline Company Age & $\mathrm{F}$ & $\%$ \\
\hline $1-5$ year & 49 & 19,2 \\
\hline 6-10 year & 48 & 18,8 \\
\hline 11-15 year & 36 & 14,1 \\
\hline 16 year and above & 122 & 47,8 \\
\hline Total & 255 & 100,0 \\
\hline Legal Structure & $\mathrm{F}$ & $\%$ \\
\hline Limited company & 172 & 67,5 \\
\hline Joint Stock Company & 83 & 32,5 \\
\hline Total & 255 & 100,0 \\
\hline Family Business? & $\mathrm{F}$ & $\%$ \\
\hline Yes & 132 & 51,8 \\
\hline No & 123 & 48,2 \\
\hline Total & 255 & 100,0 \\
\hline $\begin{array}{c}\text { Part of the a Company } \\
\text { Group? }\end{array}$ & $\mathrm{F}$ & $\%$ \\
\hline Yes & 54 & 21,2 \\
\hline No & 201 & 78,8 \\
\hline Total & 255 & 100,0 \\
\hline Number of employees & $\mathrm{F}$ & $\%$ \\
\hline $10-49$ & 195 & 76,5 \\
\hline
\end{tabular}


ISSN 2349-2325 (Online); DOI: 10.16962/EAPJFRM/issn. 2349-2325/2015; Volume 9 Issue 4 (2018)

\begin{tabular}{|c|c|c|}
\hline $50-249$ & 60 & 23,5 \\
\hline Total & 255 & 100,0 \\
\hline Sector & $\mathrm{F}$ & $\%$ \\
\hline \multicolumn{3}{|l|}{ Other Manufacturing } \\
\hline (Metal, Software, Shoes, & 23 & 9,0 \\
\hline \multicolumn{3}{|l|}{ Petroleum, etc.) } \\
\hline Automotive & 6 & 2,4 \\
\hline Construction & 18 & 7,1 \\
\hline Furniture and Wood & 26 & $10 ?$ \\
\hline \multicolumn{3}{|l|}{ Products } \\
\hline Food & 26 & 10,2 \\
\hline Wholesale And Retail Trade & 61 & 23,9 \\
\hline Transport And Storage & 20 & 7,8 \\
\hline Textile & 21 & 8,2 \\
\hline \multicolumn{3}{|l|}{ Information and } \\
\hline Communication & 20 & 7,8 \\
\hline \multicolumn{3}{|l|}{ Technologies } \\
\hline Human Health and Social & 7 & 27 \\
\hline Services & & \\
\hline Culture Arts Entertainment & 6 & 24 \\
\hline Leisure \& Sports & & \\
\hline Other & 21 & 8,2 \\
\hline Total & 255 & 100,0 \\
\hline Gender & $\mathrm{F}$ & $\%$ \\
\hline Female & 73 & 28,6 \\
\hline Male & 182 & 71,4 \\
\hline Total & 255 & 100,0 \\
\hline
\end{tabular}


ISSN 2349-2325 (Online); DOI: 10.16962/EAPJFRM/issn. 2349-2325/2015; Volume 9 Issue 4 (2018)

\begin{tabular}{|c|c|c|}
\hline Marital status & $\mathrm{F}$ & $\%$ \\
\hline Married & 157 & 61,6 \\
\hline Single & 98 & 38,4 \\
\hline Total & 255 & 100,0 \\
\hline Age & $\mathrm{F}$ & $\%$ \\
\hline $20-25$ & 32 & 12,5 \\
\hline $26-35$ & 104 & 40,8 \\
\hline $36-45$ & 79 & 31,0 \\
\hline $46-55$ & 35 & 13,7 \\
\hline 56 and above & 5 & 2,0 \\
\hline Total & 255 & 100,0 \\
\hline Education & $\mathrm{F}$ & $\%$ \\
\hline Primary school & 12 & 4,7 \\
\hline Middle School & 15 & 5,9 \\
\hline High school & 87 & 34,1 \\
\hline Associate Degree & 21 & 8,2 \\
\hline Bachelors & 108 & 42,4 \\
\hline Graduate & 12 & 4,7 \\
\hline Total & 255 & 100,0 \\
\hline Position in the company & $\mathrm{F}$ & $\%$ \\
\hline Business Owner & 58 & 22,7 \\
\hline Business Manager & 98 & 38,4 \\
\hline Finance Manager & 55 & 21,6 \\
\hline Accounting Manager & 32 & 12,5 \\
\hline $\begin{array}{c}\text { Company Manager in Other } \\
\text { Statuses }\end{array}$ & 12 & 4,7 \\
\hline
\end{tabular}


ISSN 2349-2325 (Online); DOI: 10.16962/EAPJFRM/issn. 2349-2325/2015; Volume 9 Issue 4 (2018)

\begin{tabular}{ccc}
\hline Total & 255 & 100,0 \\
\hline Experience & F & $\%$ \\
\hline $1-5$ Years & 116 & 45,5 \\
$6-10$ Years & 61 & 23,9 \\
$11-20$ Years & 63 & 24,7 \\
$21-30$ Years & 12 & 4,7 \\
31 and more & 3 & 1,2 \\
Total & 255 & 100,0 \\
\hline
\end{tabular}

Table 2: One Sample t test

\begin{tabular}{cc}
$\mathrm{N}$ & Mean \\
\hline 255 &, 6858
\end{tabular}

$$
\text { Test Value }=0
$$

Overconfidence level

$\begin{array}{cccr}\mathrm{t} & \mathrm{df} & \text { Sig. } & \text { Mean Dif. } \\ 59,894 & 254 & , 000 & , 68580\end{array}$

Table 3: The correct response rate of the participants to the questions of overconfidence scale

\begin{tabular}{cc}
\hline $\mathrm{N}$ & 255 \\
\hline Mean &, 2808 \\
\hline Median &, 3000 \\
\hline Mod &, 30 \\
\hline
\end{tabular}

Table 4: Kruskal Wallis test of the first source of financing according to overconfidence levels

Overconfidence level N Mean Rank




\section{ELK ASIA PACIFIC JOURNAL OF FINANCE AND RISK MANAGEMENT}

ISSN 2349-2325 (Online); DOI: 10.16962/EAPJFRM/issn. 2349-2325/2015; Volume 9 Issue 4 (2018)

\begin{tabular}{c|c|c|c|}
\hline $\begin{array}{c}\text { What is the first source of the } \\
\text { financing you use in the }\end{array}$ & Low overconfidence & 101 & 126,38 \\
financing of your activities? & Average overconfidence & 68 & 127,04 \\
$\begin{array}{c}\text { (1: Firm Profit, 2: Borrowing } \\
\text { from Partners, 3: Short-term } \\
\text { external borrowing, 4: Long- } \\
\text { term external borrowing, 5: } \\
\text { Other) }\end{array}$ & Total & 255 & \\
\hline Chi Square & & & \\
df &, 243 & \\
Sig. & 2 & \\
\hline
\end{tabular}

Table 5: Kruskal Wallis test of the second source of financing according to overconfidence levels

\begin{tabular}{c|c|c|c}
\hline & Overconfidence level & N & Mean Rank \\
\hline What is the second source of & Low overconfidence & 101 & 122,22 \\
the financing you use in the & Average overconfidence & 68 & 141,53 \\
financing of your activities? (1: & High overconfidence & 86 & 124,09 \\
$\begin{array}{c}\text { Firm Profit, 2: Borrowing from } \\
\text { Partners, 3: Short-term external } \\
\text { borrowing, 4: Long-term } \\
\text { external borrowing, 5: Other) }\end{array}$ & Total & 255 & \\
\hline Chi Square & & & \\
df & 3,466 & \\
Sig. & 2 & \\
\end{tabular}


Table 6: Kruskal Wallis test of the third source of financing according to overconfidence levels

\begin{tabular}{l|c|c|c}
\hline \multicolumn{2}{l}{ Overconfidence level } & N & Mean Rank \\
\hline $\begin{array}{l}\text { What is the third source of the } \\
\text { financing you use in the }\end{array}$ & Low overconfidence & 101 & 123,44 \\
financing of your activities? (1: & Average overconfidence & 68 & 135,97 \\
Firm Profit, 2: Borrowing from & High overconfidence & 86 & 127,06 \\
Partners, 3: Short-term external \\
borrowing, 4: Long-term \\
$\begin{array}{c}\text { external borrowing, 5: Other) } \\
\text { Chi Square }\end{array}$ & Total & \\
\hline df & & & \\
Sig. & \multicolumn{2}{c}{} \\
\hline
\end{tabular}

Table 7: Means of the expected rates of return on investment

\begin{tabular}{ccc}
\hline & Return on investment & Expected return on investment \\
\hline $\mathrm{N}$ & 255 & 255 \\
Mean & 2,47 & 3,69 \\
\hline
\end{tabular}

Table 8: Frequency analysis of rate of return nd expected return

\begin{tabular}{cccc}
\hline & $\mathrm{f}$ & $\%$ \\
\hline$\% 10$ and less (1) & 91 & 35,7 \\
$\% 21-\% 20$ & $(2)$ & 44 & 17,3 \\
$\% 31-\% 40$ & $(4)$ & 71 & 27,8 \\
$\% 41-\% 50$ & $(5)$ & 27 & 10,6 \\
$\% 51-\% 60$ & $(6)$ & 11 & 4,3 \\
\hline
\end{tabular}




\begin{tabular}{|c|c|c|}
\hline$\% 61$ and above (7) & 8 & 3,1 \\
\hline \multirow[t]{2}{*}{ Total } & 255 & 100,0 \\
\hline & $\mathrm{f}$ & $\%$ \\
\hline$\% 10$ and less (1) & 48 & 18,8 \\
\hline$\% 11-\% 20$ & 42 & 16,5 \\
\hline$\% 21-\% 30$ & 55 & 21,6 \\
\hline$\% 31-\% 40$ & 21 & 8,2 \\
\hline$\% 41-\% 50$ & 20 & 7,8 \\
\hline$\% 51-\% 60$ & 24 & 9,4 \\
\hline$\% 61$ and above (7) & 45 & 17,6 \\
\hline Total & 255 & 100,0 \\
\hline
\end{tabular}

Table 10: One-way variance analysis according to Overconfidence level

\begin{tabular}{ccc}
\hline df & f & Sig. \\
\hline 2 &, 540 &, 584 \\
252 & & \\
254 & & \\
\hline
\end{tabular}

Table 11: The relationship between the expected return on investment and the Overconfidence level

$\begin{array}{cc}\text { In general, how } & \text { In general, how } \\ \text { many percentages } & \text { many returns do } \\ \text { do you get from } & \text { you expect from } \\ \text { your business } & \text { your business } \\ \text { investments? } & \text { investments? }\end{array}$




\begin{tabular}{cccc}
\hline & $\begin{array}{c}\text { Pearson Corelation } \\
\text { Coefficient }\end{array}$ &,$- 142^{*}$ &,- 101 \\
CALSCO & Sig. &, 024 &, 106 \\
& $\mathrm{~N}$ & 255 & 255 \\
\hline
\end{tabular}

Table 12: Frequency of loss from investments perceived as a profitable investment

\begin{tabular}{cccc}
\hline & & $\mathrm{f}$ & $\%$ \\
\hline Often & 13 & 5,1 \\
Rarely & 175 & 68,6 \\
\cline { 3 - 3 } Never & 67 & 26,3 \\
\cline { 3 - 3 } Total & 255 & 100,0 \\
\cline { 3 - 3 }
\end{tabular}

Table 13: Kruskal Wallis test between overconfidence and loss of the investments

\begin{tabular}{|c|c|c|}
\hline \multirow{5}{*}{ Overconfidence level } & $\begin{array}{c}\text { Are you getting any damage from } \\
\text { projects you see as a profitable } \\
\text { investment? }\end{array}$ & $\mathrm{N}$ \\
\hline & Often & 13 \\
\hline & Rarely & 175 \\
\hline & Never & 67 \\
\hline & Total & 255 \\
\hline \multicolumn{3}{|c|}{ Overconfidence level } \\
\hline Chi Square & \multicolumn{2}{|c|}{1,615} \\
\hline $\mathrm{df}$ & \multicolumn{2}{|l|}{2} \\
\hline Sig. & \multicolumn{2}{|l|}{,446 } \\
\hline
\end{tabular}


Table 14: Dividend rate of companies

\begin{tabular}{c|c|c}
\hline Statements & $\mathrm{f}$ & $\%$ \\
\hline Between 1\% and 10\% of the distributable dividend & 80 & 31,4 \\
\hline Between 11\% and 20\% of the distributable dividend. & 65 & 25,5 \\
\hline Between 21\% and 30\% of the distributable dividend. & 33 & 12,9 \\
\hline Between 31\% and 40\% of the distributable dividend & 21 & 8,2 \\
\hline Between 41\% and 50\% of the distributable dividend & 18 & 7,1 \\
\hline Between 51\% and 60\% of the distributable dividend & 16 & 6,3 \\
\hline $61 \%$ and above & 22 & 8,6 \\
\hline Total & 255 & 100,0
\end{tabular}

Table 15: Anova analysis of firms' dividend distribution rates according to their overconfidence level

\begin{tabular}{ccc}
\hline df & f & Sig. \\
\hline 2 & 3,324 &, 038 \\
252 & & \\
254 & & \\
\hline
\end{tabular}

Table 16: Anova Analysis Scheffe Test Results

\begin{tabular}{c|c|c|c}
\hline \multirow{2}{*}{ Overconfidence level (I) } & Overconfidence level (J) & Mean Dif. (I-J) & Sig. \\
\hline \multirow{2}{*}{ Low overconfidence } & Average overconfidence &, 482 &, 253 \\
\cline { 2 - 4 } & High overconfidence &, $676^{*}$ &, 046 \\
\hline \multirow{2}{*}{ Average overconfidence } & Low overconfidence &,- 482 &, 253 \\
\cline { 2 - 4 } & High overconfidence &, 194 &, 811 \\
\hline
\end{tabular}


ISSN 2349-2325 (Online); DOI: 10.16962/EAPJFRM/issn. 2349-2325/2015; Volume 9 Issue 4 (2018)

High overconfidence

\begin{tabular}{|c|c|c|}
\hline Low overconfidence &,$- 676^{*}$ &, 046 \\
\hline Average overconfidence &,- 194 &, 811 \\
\hline
\end{tabular}

Table 17: Anova analysis descriptive statistics

\begin{tabular}{cccc}
\hline & $\mathrm{N}$ & Mean & Std. Devi. \\
\hline Low overconfidence & 101 & 3,19 & 2,257 \\
Average overconfidence & 68 & 2,71 & 1,517 \\
High overconfidence & 86 & 2,51 & 1,524 \\
Total & 255 & 2,83 & 1,865 \\
\hline
\end{tabular}

Table 18: Overconfidence levels

\begin{tabular}{ccc}
\hline & $\mathrm{f}$ & $\%$ \\
\hline Low overconfidence & 101 & 39,6 \\
Average overconfidence & 68 & 26,7 \\
High overconfidence & 86 & 33,7 \\
\hline Total & 255 & 100,0 \\
\hline
\end{tabular}

Table 19: Correlation Analysis of the relationship between expected rate of return and dividend rates

$\begin{array}{cc}\text { In general, how } & \\ \text { many returns do } & \text { In general, what } \\ \text { you expect from } & \text { is your dividend } \\ \text { your business } & \text { distribution rate? } \\ \text { investments? } & \end{array}$




\begin{tabular}{|c|c|c|c|}
\hline \multirow{4}{*}{$\begin{array}{c}\text { In general, how many returns } \\
\text { do you expect from your } \\
\text { business investments? }\end{array}$} & Pearson Corelation & 1 & $227 *$ \\
\hline & Coefficient & 1 & , \\
\hline & Sig. & & ,036 \\
\hline & $\mathrm{N}$ & 86 & 86 \\
\hline \multirow{4}{*}{$\begin{array}{l}\text { In general, what is your } \\
\text { dividend distribution rate? }\end{array}$} & Pearson Corelation & \multirow{2}{*}{, $227 *$} & \multirow{2}{*}{1} \\
\hline & Coefficient & & \\
\hline & Sig. & 036 & \\
\hline & $\mathrm{N}$ & 86 & 86 \\
\hline
\end{tabular}

*Significance at 0,05 level

\section{LIST OF FIGURES}

Figure 1: Percentage of Accurate Responses to Overconfidence Scale

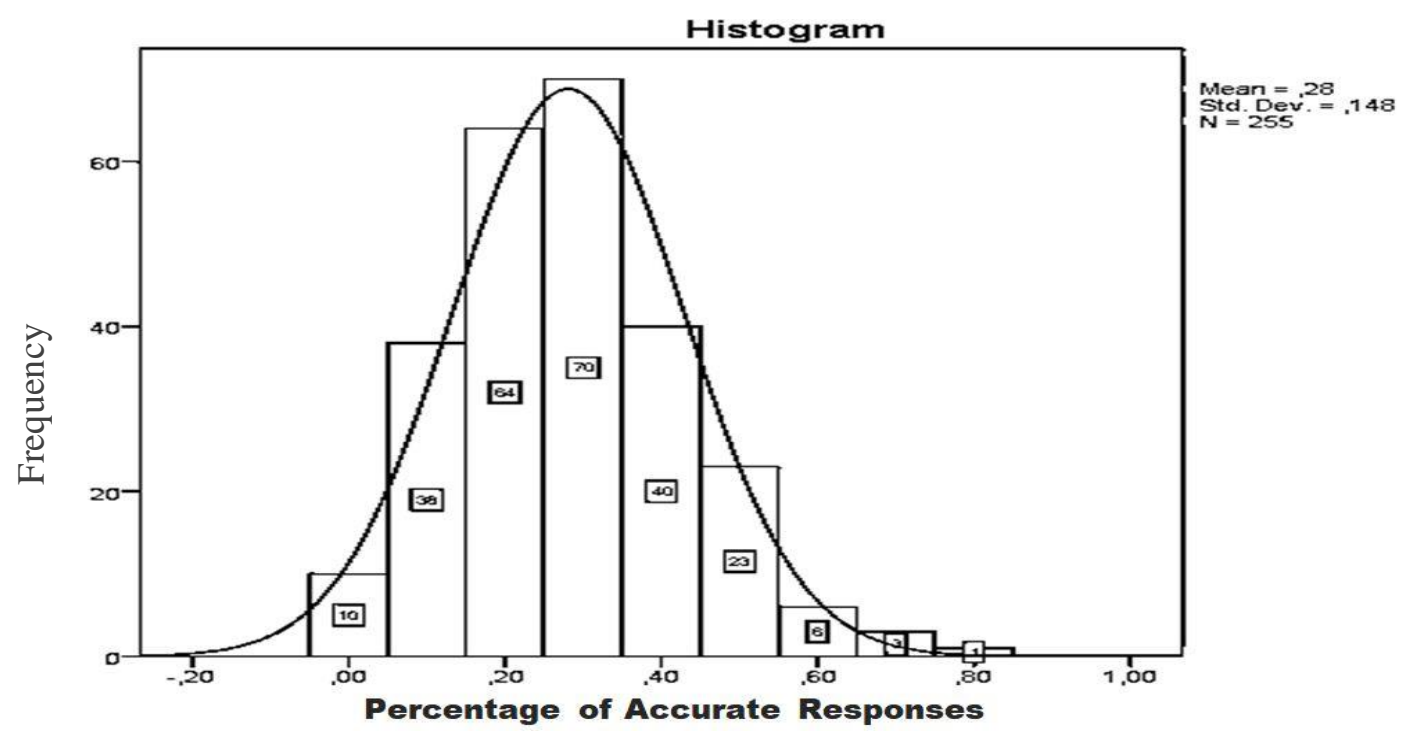


ISSN 2349-2325 (Online); DOI: 10.16962/EAPJFRM/issn. 2349-2325/2015; Volume 9 Issue 4 (2018)

Figure 2: Histogram Graph of Overconfidence of Company Officers

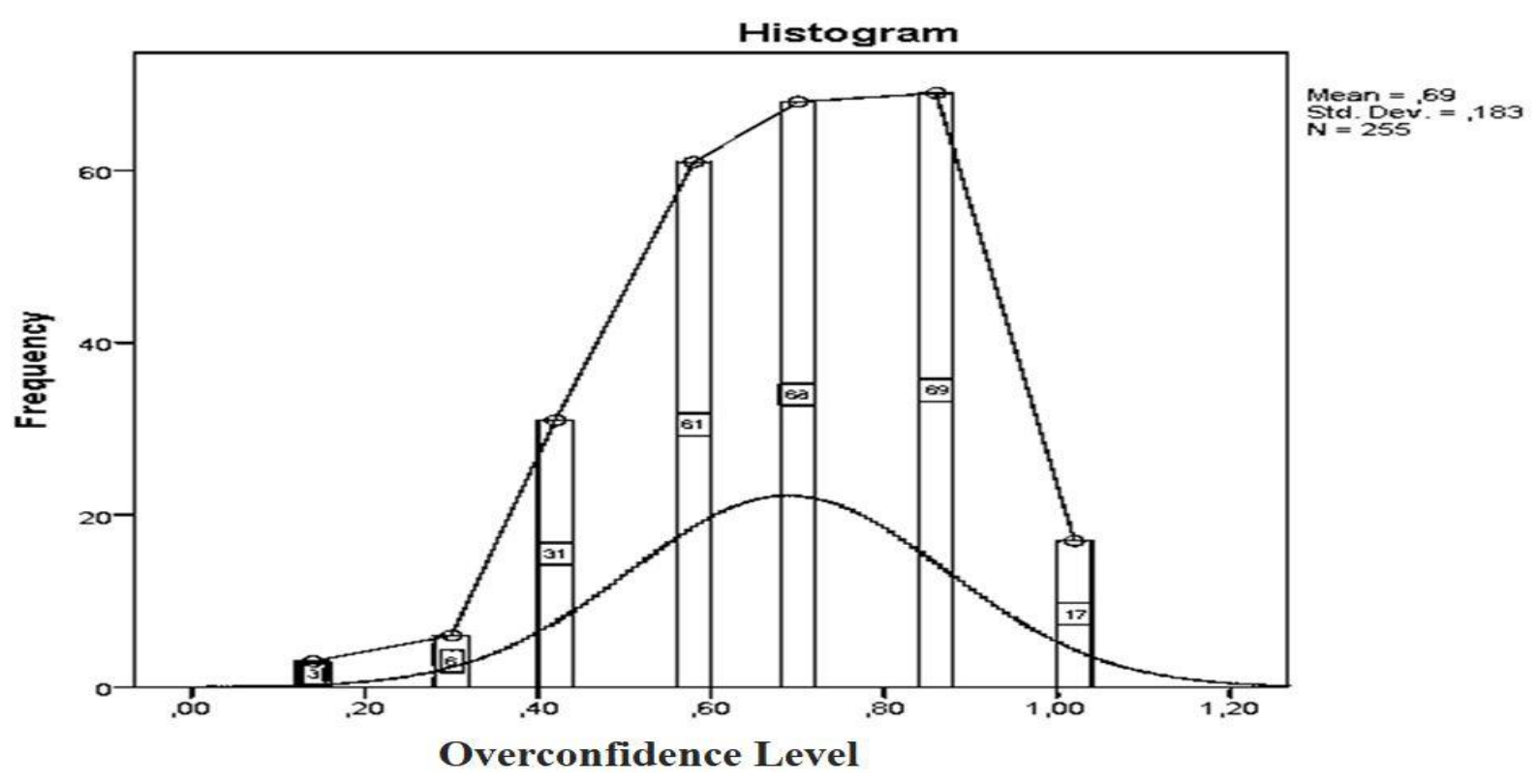

